D. Hatch $\cdot$ H. Trindade $\cdot$ L. Cardenas $\cdot$ J. Carneiro $\cdot$

\author{
J. Hawkins · D. Scholefield • D. Chadwick
}

\title{
Laboratory study of the effects of two nitrification inhibitors on greenhouse gas emissions from a slurry-treated arable soil: impact of diurnal temperature cycle
}

Received: 7 September 2004 / Revised: 21 December 2004 / Accepted: 23 December 2004 / Published online: 15 February 2005 (C) Springer-Verlag 2005

\begin{abstract}
An automated laboratory soil incubation system enabled the effects on gaseous emissions from a soil to be quantified accurately, when amended with slurry plus a nitrification inhibitor: dicyandiamide (DCD), or 3,4-dimethylpyrazole phosphate (DMPP). Nitrification inhibitors applied with slurry under simulated Portuguese conditions were very efficient in reducing $\mathrm{N}_{2} \mathrm{O}$ emission, and did not increase $\mathrm{CH}_{4}$ emissions significantly, when the soil was predominantly aerobic. The inhibitors were also indirectly effective in reducing $\mathrm{N}_{2} \mathrm{O}$ emissions due to denitrification during a subsequent anaerobic phase. All gaseous emissions followed strong diurnal patterns that were positively correlated with soil temperature and obeyed a $Q_{10}=2$ relationship. The widespread use of DCD and DMPP inhibitors with slurry applied to Portuguese soils could have the potential to reduce $\mathrm{N}_{2} \mathrm{O}$ emissions from this source by ten- to 20 -fold.
\end{abstract}

Keywords Nitrous oxide - Slurry · Greenhouse gases · Air quality $\cdot$ Nitrification inhibitor

\footnotetext{
D. Hatch $\cdot$ L. Cardenas $(\bowtie) \cdot$ J. Hawkins $\cdot$ D. Scholefield

D. Chadwick

Institute of Grassland and Environmental Research,

North Wyke,

Okehampton, EX20 2SB, UK

e-mail: laura.cardenas@bbsrc.ac.uk

Tel.: +44-1837-883533

Fax: $+44-1837-882139$

H. Trindade

Department of Plant Science and Agricultural Engineering, UTAD,

Ap. 1013 ,

5001-911 Vila Real, Portugal

J. Carneiro

Escola Superior Agraria de Castelo Branco,

Qta. Sra. De Mercules, Ap. 119,

6001-909 Castelo Branco, Portugal
}

\section{Introduction}

Nitrification in soils is an environmentally important process as it is responsible for the conversion of relatively immobile $\mathrm{NH}_{4}^{+}-\mathrm{N}$ into $\mathrm{NO}_{3}^{-}$, accompanied by the production of several gaseous $\mathrm{N}$ forms, including $\mathrm{N}_{2} \mathrm{O}$. The $\mathrm{NO}_{3}^{-}$ produced by nitrification may then be lost from agricultural systems by subsequent leaching or, through denitrification, may be converted to $\mathrm{N}_{2} \mathrm{O}$ and $\mathrm{N}_{2}$ gases. $\mathrm{N}_{2} \mathrm{O}$ is a potent greenhouse gas and stratospheric ozone destroyer and in order to comply with the Kyoto Protocol on greenhouse gas emissions, EU countries must achieve an $8 \%$ reduction of the 1990 levels by 2008-2012. Various mitigation options to reduce $\mathrm{N}_{2} \mathrm{O}$ emissions have been proposed (e.g. Erickson and Keller 1997; Oenema et al. 1997). A potentially effective strategy for $\mathrm{N}_{2} \mathrm{O}$ emission reduction would be inhibition of nitrification and denitrification, in situations where these processes can operate at high rates. While rates of both of these biological processes will depend on availability of substrates and labile energy sources, they are very sensitive to temperature and soil water content, and so it might be expected that worst-case scenarios may arise where agricultural land is managed intensively in a climate that is both warm and wet with soil conditions that fluctuate frequently between wet and dry. The north of Portugal may represent an extreme scenario in these respects with high seasonal rainfall, hot summers and highly intensive dairy farming, involving large annual inputs of inorganic and slurry-based fertilizer $\mathrm{N}$ to support two silage crops per year (Trindade et al. 1997).

Many of the dairy systems in use in Portugal involve small farms with relatively large herds that are housed all year round and which generate appreciable amounts of slurry for disposal on restricted areas of the farm. The soil conditions in October, when the land is being prepared for cultivation, are often still moist, with average maximum/ minimum daily temperatures of about $20 / 10^{\circ} \mathrm{C}$, suggesting that conditions could be highly conducive for appreciable microbial activity. A typical scenario would be application 
of cattle slurry to the soil surface when it is warm and moist (promoting nitrification), followed by a period of autumn rain creating conditions which then become anaerobic (promoting denitrification). We hypothesised that inhibition of nitrification could be used to reduce $\mathrm{N}_{2} \mathrm{O}$ emissions directly, and also indirectly, by limiting the supply of substrate (viz. $\mathrm{NO}_{3}^{-}$) available for denitrification. However, it is important to check whether such inhibition could affect $\mathrm{CH}_{4}$ fluxes from slurry-amended soil, either by compromising $\mathrm{CH}_{4}$ oxidation potential (leading to increased $\mathrm{CH}_{4}$ emission) or by reducing labile $\mathrm{C}$ production (leading to reduced emissions; see $\mathrm{Xu}$ et al. 2002).

Dicyandiamide (DCD) is a nitrification inhibitor that has been evaluated under field (Merino et al. 2001) and laboratory (Vallejo et al. 2001) conditions, mixed with either inorganic (Majumdar et al. 2002) or organic (Merino et al. 2001 ) sources of $\mathrm{NH}_{4}^{+}-\mathrm{N}$, but can be expensive when high rates are needed to be effective over the longer term. It is also prone to leaching, representing a significant source of $\mathrm{N}$ loss (Teske and Matzel 1988) and can have deleterious effects on clover growth (Macadam et al. 2003). The recent development (Zerulla et al. 2001) of a new nitrification inhibitor, 3,4-dimethylpyrazole phosphate (DMPP), offers advantages over DCD. It is not as liable to loss through leaching (Fettweis et al. 2001) and is effective at much smaller doses (Weiske et al. 2001) and, therefore unlikely to have damaging effects on the crop plant. It has the potential to reduce losses of $\mathrm{N}_{2} \mathrm{O}$ if added to slurry (Dittert et al. 2001) and was more effective than DCD when formulated with fertilizer (Weiske et al. 2001). However, there is only limited information on the effects of DMPP formulated with fertilizers and only recently has attention been paid to the possibility of using inhibitors with slurry (Dittert et al. 2001; Macadam et al. 2003). Moreover, in these studies there has been little acknowledgement of the need to take account of rapidly changing patterns of gaseous emissions during nitrification and subsequent denitrification, due to diurnal temperature variation (see Christensen 1983; Chadwick et al. 2000; Sanchez et al. 2001) and so attempts to make accurate quantitative assessments may have been compromised.

Laboratory experimentation offers the possibility of better evaluation of treatment effects through closer control of environmental variables and the capability of taking measurements with high temporal resolution. In the present study, we employed a soil incubation technique with a Heenriched atmosphere (Scholefield et al. 1997) which has now been further developed for automated, direct measurements of $\mathrm{N}_{2} \mathrm{O}, \mathrm{N}_{2}$ and $\mathrm{CH}_{4}$ gas fluxes (Cardenas et al. 2003). The new system was used to evaluate the effectiveness of DCD and DMPP in reducing nitrification and subsequent denitrification when added with cattle slurry to a Portuguese soil, incubated under simulated autumn conditions of temperature and water content. Thus, a typical diurnal temperature regime was imposed and fluxes were measured approximately every $2 \mathrm{~h}$ over a period of 36 days.

\section{Materials and methods}

Soil was collected in spring 2004 from the 0 - to 20 -cm layer of a cultivated soil, low in organic matter content (Cambisol, 0.64\% organic $\mathrm{C}, 0.06 \%$ total $\mathrm{N}, \mathrm{pH} 5.5$ ) from Castelo Branco in central Portugal and partially dried to a soil moisture content of $11.5 \%(\mathrm{w} / \mathrm{w})$ at room temperature, before sieving $(<2 \mathrm{~mm})$, mixing and transportation to the UK in a cool box. The soil was packed into 12 cylinders (143 $\mathrm{mm}$ diameter, $120 \mathrm{~mm}$ height) to achieve a bulk density of $1.3 \mathrm{~g} \mathrm{~cm}^{-3}$ (2.2 $\mathrm{kg}$ soil to each cylinder), leaving a 20-mm headspace. The base of each cylinder was covered with a nylon mesh $(1.0 \mathrm{~mm})$ to retain the soil. The cylinders were then placed in individual trays, each containing the required volume of water to bring the soil to $90 \%$ field capacity $(26 \% \mathrm{w} / \mathrm{w})$. Soils were analysed for $\mathrm{NH}_{4}^{+}$and $\mathrm{NO}_{3}^{-}$, both before, and after wetting (Table 1) by extraction in $2 \mathrm{M} \mathrm{KCl}$ for $1 \mathrm{~h}$ on an orbital shaker and the extracts were filtered through Whatman no. 5 filter paper before determination by automated colorimetry (Kamphake et al. 1967; Searle 1984). The cylinders fitted precisely into the incubation vessels which were sealed to exclude atmospheric $\mathrm{N}_{2}$ and housed in a temperature-controlled cabinet. Stainless steel air lines from each vessel were connected to two gas chromatographs (GCs): one to analyse $\mathrm{N}_{2} \mathrm{O}$ (electron capture detector) and a second for $\mathrm{N}_{2}$ (He ionisation detector), as described in Cardenas et al. (2003), which can also be used to measure $\mathrm{CH}_{4}$. Briefly, the system enables gas fluxes to be analysed by first purging the soils in the chambers with a mixture of $80 \% \mathrm{He}$ and $20 \% \mathrm{O}_{2}$, directed through the base of the cylinders to remove atmospheric $\mathrm{N}_{2}$ from the soil, headspace and gas lines (flow-through mode). The flow was then directed to the vessels via the lid (flow-over mode), so that emissions of $\mathrm{N}_{2} \mathrm{O}$ and $\mathrm{N}_{2}$ from the soil surface were transported in the carrier gas stream. Effluent gases from each of the 12 chambers passed through an outlet in the lid to an actuated 16-port selection valve, either for analyses in the GCs, or vented to the atmosphere. Detection limits for $\mathrm{N}_{2} \mathrm{O}$ and $\mathrm{N}_{2}$ are typically 2.3 and $9.6 \mathrm{~g} \mathrm{~N} \mathrm{ha}^{-1}$ day $^{-1}$, respectively, and $21 \mathrm{~g} \mathrm{C} \mathrm{ha}^{-1}$ day $^{-1}$ for $\mathrm{CH}_{4}$.

Table 1 Analyses of the Portuguese soil (expressed on a dry weight basis), as supplied at the start of experiment (Before wetting), after wetting to $90 \%$ field capacity (Pre-incubation) and after the experiment (Post-incubation). DCD Dicyandiamide, DMPP 3,4dimethylpyrazole phosphate

\begin{tabular}{lcclll}
\hline & $\begin{array}{l}\mathrm{NH}_{4}^{+}-\mathrm{N} \\
(\mathrm{mg} \mathrm{N} \\
\left.\mathrm{kg}^{-1}\right)\end{array}$ & $\begin{array}{l}\mathrm{NO}_{3}^{-}-\mathrm{N} \\
\left(\mathrm{mg} \mathrm{N}^{-1}\right)\end{array}$ & $\begin{array}{l}\text { Bulk } \\
\mathrm{kg}^{-1} \\
\left(\mathrm{~g} \mathrm{~cm}^{-3}\right)\end{array}$ & $\begin{array}{l}\text { Soil } \\
\text { moisture } \\
\left(\mathrm{g} \mathrm{100}^{-1}\right)\end{array}$ & $\begin{array}{l}\text { \% Water- } \\
\text { filled pore } \\
\text { space }\end{array}$ \\
\hline $\begin{array}{l}\text { Before wetting } \\
\text { Pre-incubation }\end{array}$ & 0.65 & 2.29 & & 11.54 & \\
Post-incubation & 0.86 & 4.62 & 1.3 & 22.01 & 56.4 \\
Control & 1.7 & 8.5 & 1.3 & 21.9 & 55.9 \\
Slurry only & 1.3 & 36.0 & 1.3 & 26.8 & 68.4 \\
$\begin{array}{l}\text { Slurry+DCD } \\
\text { Slurry+DMPP }\end{array}$ & 29.8 & 4.9 & 1.3 & 26.8 & 68.4 \\
\hline
\end{tabular}


Fresh dairy slurry was collected from a dairy dispersal yard (within $24 \mathrm{~h}$ of deposition by cows fed predominantly on grass silage) and analysed for the constituents shown in Table 2, both before, and after sieving (a 4-mm mesh was used to remove larger particulate matter). Total $\mathrm{N}$ was determined using Kjeldahl analysis and total $\mathrm{C}$ using an elemental analyser (Carlo-Erba). Inorganic $\mathrm{N}$ was extracted from slurry with $2 \mathrm{M} \mathrm{KCl}$ and determined as for soil extracts. Volatile fatty acids (VFA) content was assessed by gas chromatography-mass spectrometry (Hobbs et al. 1999) after centrifuging the slurry $(50 \mathrm{ml})$ at $5,000 \mathrm{~g}$ for 30 $\mathrm{min}$. The sieved slurry was added to the soil in nine vessels, via a secondary chamber fitted to the centre of each lid, after first flushing with $\mathrm{He}$ to remove atmospheric $\mathrm{N}_{2}$. The slurry was applied to the soil surface at a rate equivalent to $64 \mathrm{~m}^{3} \mathrm{ha}^{-1}$ and provided an application of $85 \mathrm{~kg} \mathrm{~N}$ $\mathrm{ha}^{-1}\left(21.6 \mathrm{~kg} \mathrm{NH}_{4}^{+}-\mathrm{N} \mathrm{ha}^{-1}\right)$. The effluent gases from the flushed slurry were bubbled through a trap containing 100 $\mathrm{ml}$ of $0.001 \mathrm{M} \mathrm{H}_{3} \mathrm{PO}_{4}$ to collect any $\mathrm{NH}_{3}$ emitted from the slurry $(<0.1 \%$ of the total $\mathrm{N}$ in slurry was removed by flushing with $\mathrm{He}$ ). The remaining three vessels were without slurry to act as controls. Of the nine vessels receiving slurry, three were without inhibitor (slurry only), three were treated with DCD at a rate of $5 \%$ slurry-N (supplied as the equivalent DCD-N) and three others received slurry treated with DMPP at $1 \%$ slurry-N (supplied as the equivalent DMPP-N).

The incubation lasted 36 days with the temperature controlled in a $12 \mathrm{~h}$ day $/ 12 \mathrm{~h}$ night cycle of $20 / 10^{\circ} \mathrm{C}$ and with the $\mathrm{He}$ plus $\mathrm{O}_{2}$ gas mixture set at a nominal flowrate through the vessels of $10 \mathrm{ml} \mathrm{min}{ }^{-1}$ (at $20^{\circ} \mathrm{C}$ ). Previous measurements showed that lowering the temperature from $20^{\circ} \mathrm{C}$ to $10^{\circ} \mathrm{C}$ reduced the flowrate by only $7.6 \%$. Measurements of emissions of $\mathrm{N}_{2} \mathrm{O}$ and $\mathrm{N}_{2}$ and $\mathrm{CH}_{4}$ were continuous for the first 22 days, until fluxes of these three gases were minimal (i.e. below the detection limits) when measurements were stopped. The incubated samples were then kept under the same flushing conditions to let the system stabilise to baseline conditions. After 31 days' incubation, the $\mathrm{O}_{2}$ supply was removed from the vessels to induce anaerobic conditions and detailed measurements then recommenced to test the denitrification potential of the soils and the temporal efficacy of the nitrification inhibitors.

Table 2 Slurry analyses expressed on a wet weight basis (w/w), before and after sieving through a 4-mm mesh to remove larger particulate matter

\begin{tabular}{|c|c|c|}
\hline Compound & Not sieved & Sieved \\
\hline $\mathrm{NH}_{4}^{+}-\mathrm{N}\left(\mathrm{mg} \mathrm{N} \mathrm{g}^{-1}\right.$ slurry) & 0.33 & 0.33 \\
\hline $\mathrm{NO}_{3}^{-}-\mathrm{N}$ (mg $\mathrm{N} \mathrm{g}^{-1}$ slurry) & 0 & 0 \\
\hline$\%$ Total N (Kjeldhal) & 0.14 & 0.13 \\
\hline$\%$ Dry matter & 4.0 & 3.1 \\
\hline $\mathrm{pH}$ & 7.6 & 7.8 \\
\hline$\%$ Organic C & & 0.82 \\
\hline$\%$ Total C & & 0.92 \\
\hline$\%$ Water-soluble C & & 0.16 \\
\hline Total volatile fatty acids $\left(\mathrm{mg} \mathrm{l}^{-1}\right)$ & 422 & 137 \\
\hline
\end{tabular}

Flow rates through the vessels were maintained by increasing the flow of He to compensate for the absence of $\mathrm{O}_{2}$. Five days later, gaseous emission measurements were stopped, the vessels were opened and the soils were then removed and subsamples taken for post-incubation analyses (Table 1).

\section{Statistical analysis and treatment of results}

Total emissions in each vessel were estimated from the area under the curve of the recorded fluxes (Genstat version 7). Statistical analysis of the total emissions was carried out by ANOVA and a regression analysis was used to explore the effect of temperature on $\mathrm{N}_{2} \mathrm{O}$ flux (Genstat version 7).

\section{Results}

Phase 1: nitrifying conditions during days $0-31$

Figure 1 shows the pattern of $\mathrm{N}_{2} \mathrm{O}$ emission for the slurryonly treatment from measurements taken over the first 22 days of incubation, during which there were two emission events (for clarity, the other treatments have been omitted from Fig. 1, as there were no other discernible emissions during this phase). The first, minor emissions, occurred immediately after the addition of amendments, lasting about 2.5 days in all treatments (ca. $0.01 \mathrm{~kg} \mathrm{~N} \mathrm{ha}^{-1}$ day $^{-1}$ ), except in the control (nothing added) where no emission was detected. We suspect that these resulted from low rates of denitrification, stimulated by additions of liquid to the soil. In support of this assumption, we could detect only small fluxes of $\mathrm{N}_{2}$ during this period (data not shown), but these were close to the detection limit of the system and there was no $\mathrm{N}_{2}$ from the other treatments, strongly suggesting that the $\mathrm{N}_{2} \mathrm{O}$ from the slurry-only treatment was due to nitrification. The main feature of Fig. 1 is the $\mathrm{N}_{2} \mathrm{O}$ emission from the slurry-only treatment, beginning 8 days after addition of amendments, with the peak emission on day 15 and continuing until day 22, when fluxes were negligible and phase 1 measurements ceased. The $\mathrm{N}_{2} \mathrm{O}$ emitted in this phase was significantly different from the other treatments $(P<0.05)$. The response of $\mathrm{N}_{2} \mathrm{O}$ flux to the diurnal temperature cycle was also tested. Firstly the data were modelled to describe the temporal trend by fitting a Gaussian curve $(P<0.001)$ and then a cross-correlation of the residuals was obtained from the regression. The strong diurnal pattern in emission was found to be closely correlated $(r=0.797)$ with the controlled temperature regime (with an apparent lag phase of up to $30 \mathrm{~min}$ ) and a second linear regression analysis of the residuals with temperature showed that $63.2 \%$ of the variance was accounted for. The amplitude of each diurnal cycle was of the same magnitude as the daily mean value (peak values ranging between 0.1 and 0.22 ) and the rates approximately doubled (Fig. 1) with the increase in temperature from $10^{\circ} \mathrm{C}$ to $20^{\circ} \mathrm{C}$ (i.e. $Q_{10} \approx 2$ ).

$\mathrm{CH}_{4}$ was emitted during the first 4.5 days of phase 1 , also with a strong diurnal pattern, corresponding with the 
Fig. 1 Diurnal temperature cycle $(\times)$ and $\mathrm{N}_{2} \mathrm{O}$ fluxes $(\bullet)$ from the slurry-only treatment during the aerobic (phase 1) incubation lasting from days 1 to 22 . The bar shows the maximum \pm SEM (three replicates for each data point) found in all the flux measurements. $d$ Day

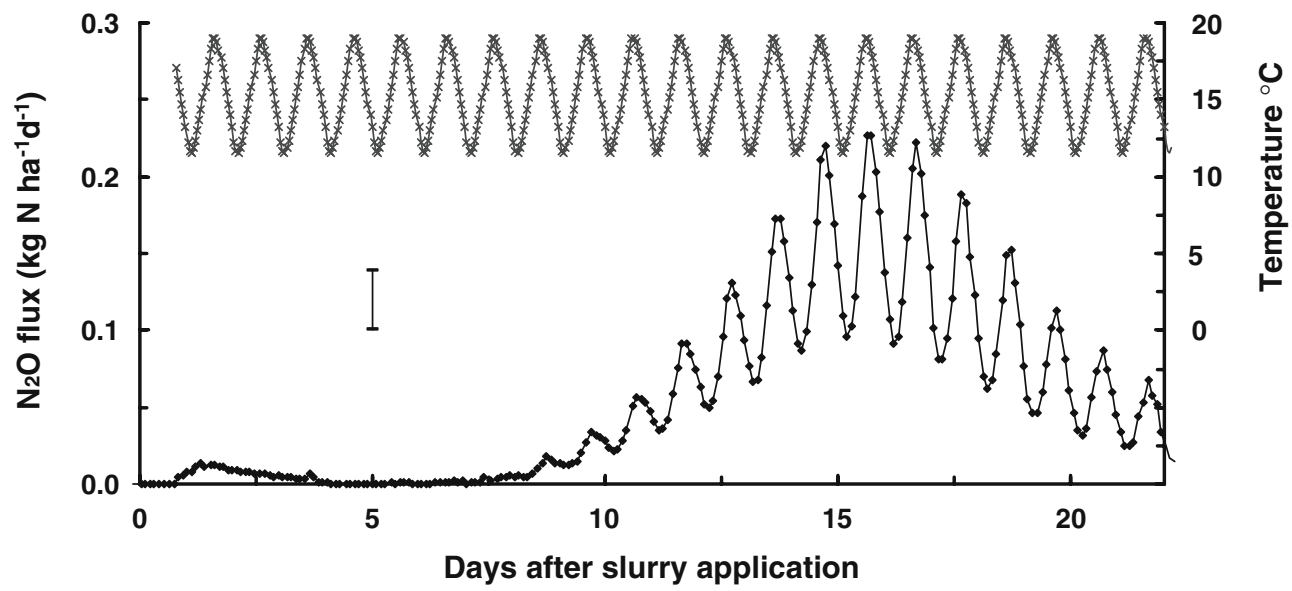

controlled temperature regime, in all except the control treatments (Fig. 2). The emissions of $\mathrm{CH}_{4}$ from the soil receiving slurry plus DCD (but not with DMPP) were consistently higher than those of the soil with slurry only (suggesting interference by this inhibitor with $\mathrm{CH}_{4}$ oxidation and/or generation), but the total amounts emitted between the treatments were not significantly different $(P>0.05)$.

Phase 2: denitrifying conditions during days 32-36

Figure $3 \mathrm{a}, \mathrm{b}$ shows emissions of $\mathrm{N}_{2} \mathrm{O}$ and $\mathrm{N}_{2}$, respectively, during 5 days, following withdrawal of the $\mathrm{O}_{2}$ supply (days 32-36). During this period (Fig. 3a) there was no difference between the slurry-only and control treatments, both of which gave much greater emissions $(P<0.05)$ of $\mathrm{N}_{2} \mathrm{O}$ compared with those receiving slurry plus inhibitors. By day 33 (ca. $37 \mathrm{~h}$ after removal of $\mathrm{O}_{2}$ ), emissions from slurry plus inhibitors had attenuated to extremely small values, whereas emissions from the control and slurry-only continued at high levels until the end of the experimental period (day 36). Rates of $\mathrm{N}_{2} \mathrm{O}-\mathrm{N}$ loss were very similar from soils with the slurry-only and control treatments and both had similar diurnal patterns. Overall, the slurry-only treatment produced fluxes which were about 2.2 times greater than in the aerobic conditions of phase 1 . However, there was no significant difference between inhibitor treatments in emissions of $\mathrm{N}_{2} \mathrm{O}$ from soil receiving slurry. All emissions varied with strong diurnal patterns that corresponded with the temperature cycle, as demonstrated by phase 1 emissions.

Emissions of $\mathrm{N}_{2}$ during this second phase began immediately and were greatest with the two inhibitor treatments $(P<0.05)$, reaching $1.3-1.5 \mathrm{~kg} \mathrm{~N}^{-1} \mathrm{day}^{-1}$ after ca. $38 \mathrm{~h}$ (Fig. 3b). Emissions of $\mathrm{N}_{2}$ from soil receiving the slurry only were again similar to the control treatment, but smaller than from soils receiving inhibitors $(P<0.05)$, rising to $0.4-0.8 \mathrm{~kg} \mathrm{~N}^{-1}$ day $^{-1}$ after 2 days. There were no emissions of $\mathrm{CH}_{4}$ during the anaerobic phase, suggesting that the source was from slurry in phase 1 and had become depleted by phase 2 .
Fig. $2 \mathrm{CH}_{4}$ fluxes from control $(\square)$, slurry-only $(\bullet)$, slurry+ dicyandiamide $(D C D)(\triangle)$ and slurry+3,4-dimethylpyrazole phosphate $(D M P P)(\circ)$ treatments during the aerobic (phase 1) incubation lasting from days 1 to 22 . The bar shows the maximum \pm SEM (three replicates for each data point) found in all the flux measurements

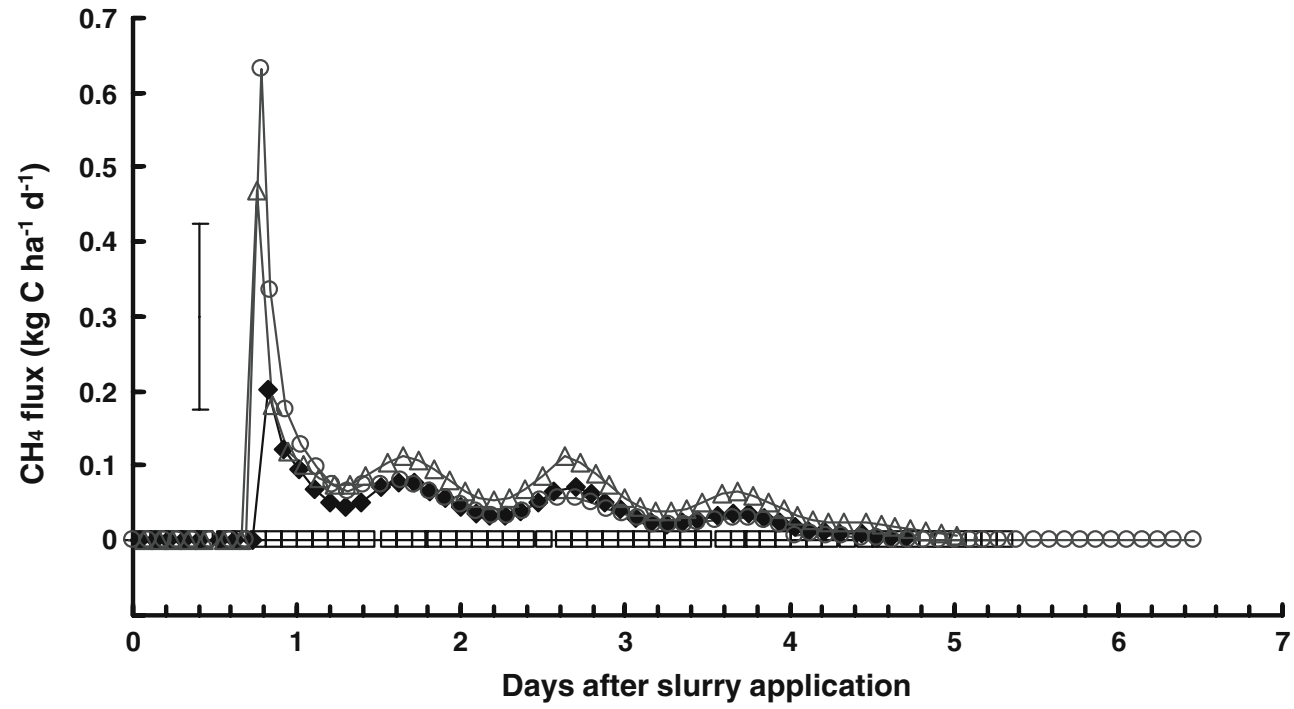


Fig. 3 a $\mathrm{N}_{2} \mathrm{O}$ fluxes and $\mathbf{b} \mathrm{N}_{2}$ fluxes from control ( $\square$ ), slurryonly $(\diamond)$, slurry+DCD $(\bullet)$ and slurry+DMPP $(0)$ treatments during the anaerobic (phase 2) incubation lasting from days 32 to 36 . The bars show the maximum \pm SEM (three replicates for each data point) found in all the flux measurements from treatments receiving slurry. For abbreviations, see Figs. 1 and 2
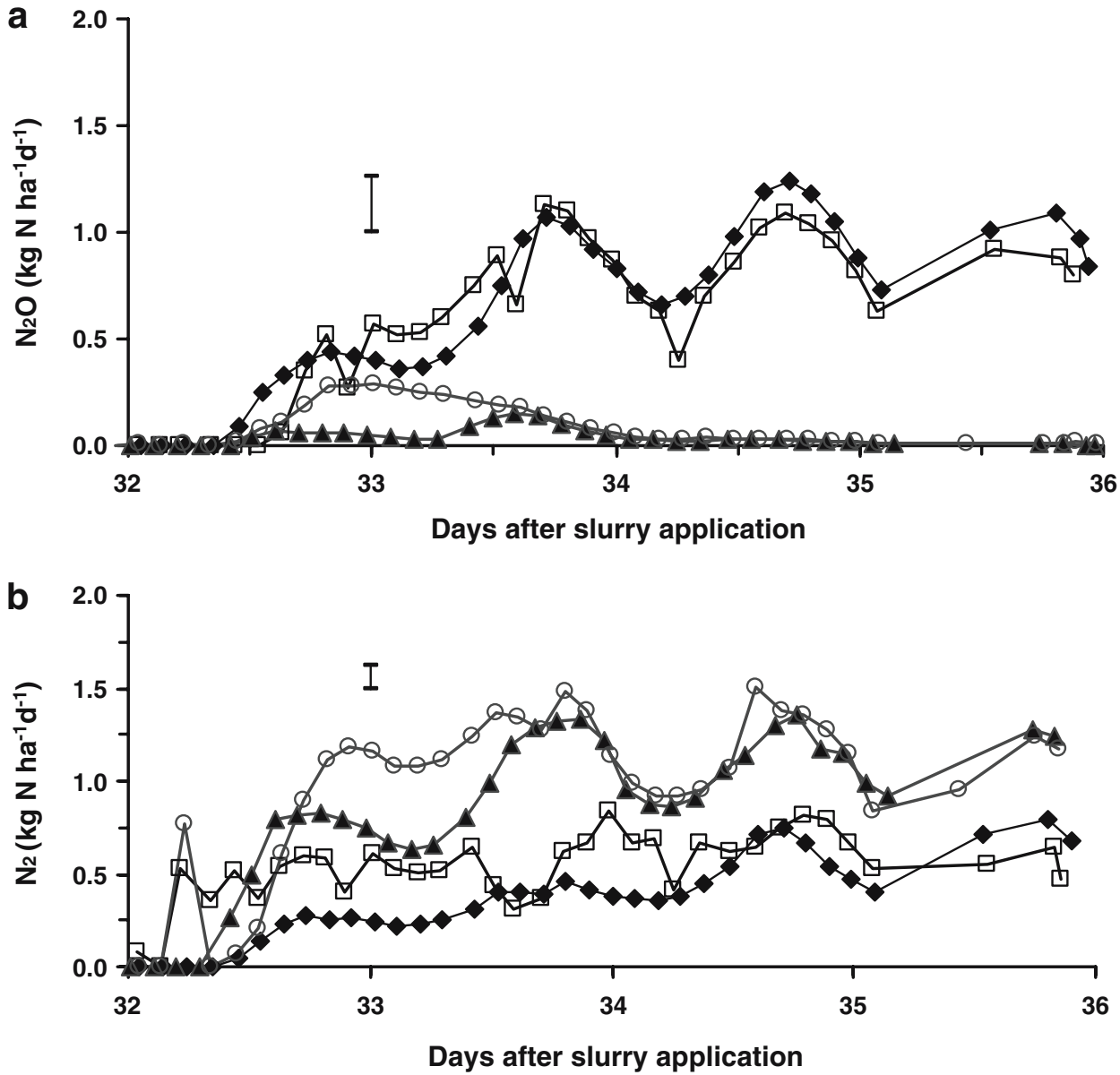

Amounts of gaseous $\mathrm{N}$ and $\mathrm{C}$ emitted overall

Figure 4 shows the total fluxes of $\mathrm{N}$ for the two phases of the 36-day incubation. There were no significant differences in the total amounts of gaseous $\mathrm{N}$ emitted (combining losses from phases 1 and 2) between the control, slurry-only, slurry plus DCD and slurry plus DMPP treatments (4.6, 5.9, 4.0 and $4.8 \mathrm{~kg} \mathrm{~N} \mathrm{ha}^{-1}$, respectively). The combined emissions
Fig. 4 Total emissions of $\mathrm{N}_{2}$ (unshaded boxes) and $\mathrm{N}_{2} \mathrm{O}$ (shaded boxes) from control, slurry-only, and slurry+inhibitor treatments from the aerobic (phase 1) plus anaerobic (phase 2 ) incubations lasting 36 days. Histograms for each treatment are the means of three replicate measurements (+SEM shown as a bar). For abbreviations, see Fig. 2

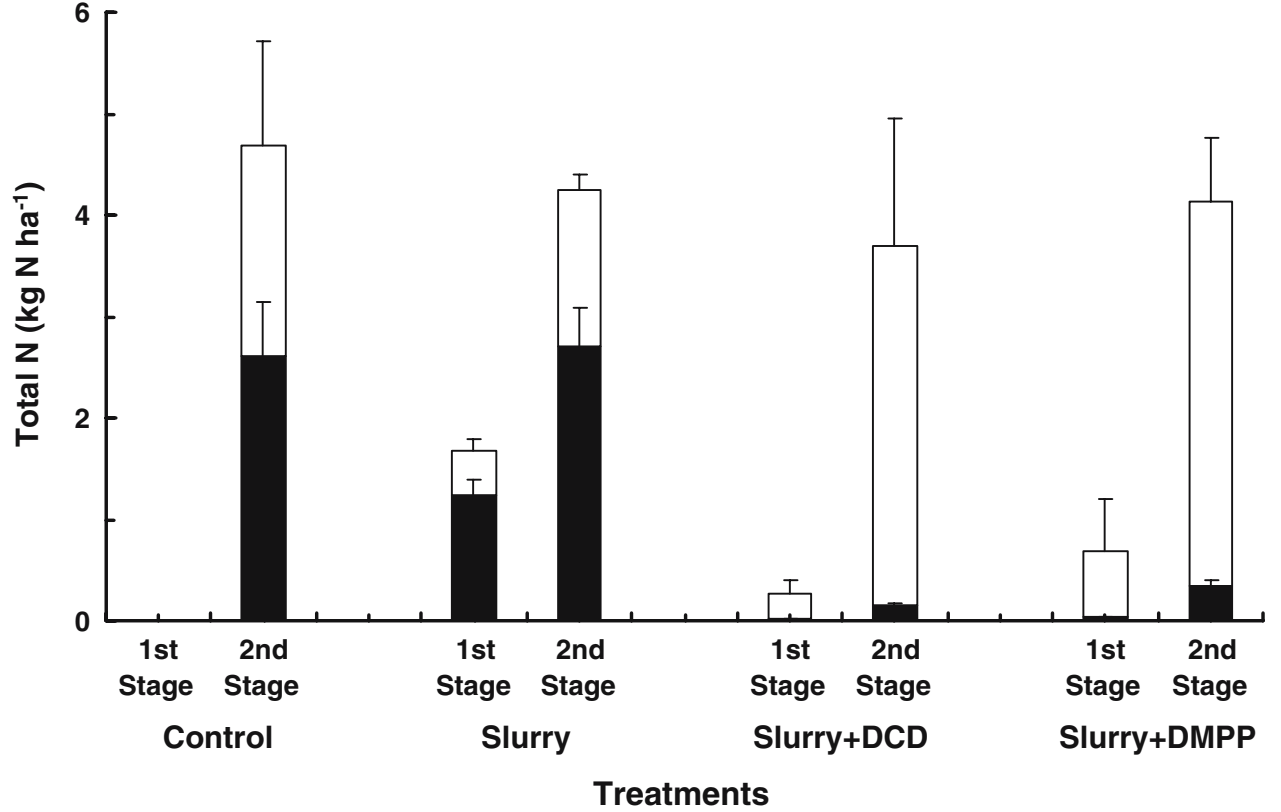


of $\mathrm{N}_{2} \mathrm{O}$ from the two phases (in the same order) amounted to $2.6,3.9,0.17$ and $0.37 \mathrm{~kg} \mathrm{~N} \mathrm{ha}^{-1}$, respectively (equivalent to mean hourly rates of $301,451,19.7$ and $42.8 \mu \mathrm{g} \mathrm{N} \mathrm{N}_{2} \mathrm{O}-\mathrm{N}$ $\mathrm{m}^{-2} \mathrm{~h}^{-1}$ ); emissions from the slurry-only treatment being significantly greater $(P<0.001)$ than from the other treatments. Total amounts emitted, particularly of $\mathrm{N}_{2}$, were likely to have been underestimated as emissions were still continuing at the termination of the experiment. However, it is unlikely that the relative amounts of $\mathrm{N}_{2} \mathrm{O}$ emitted from the treatments would have changed substantially beyond 36 days.

These results show that, relative to the slurry-only treatment, the amounts of $\mathrm{N}_{2} \mathrm{O}$ emitted from soils receiving the control, slurry plus DCD and slurry plus DMPP treatments were $64 \%, 4 \%$ and $9 \%$, respectively. The $\mathrm{N}_{2} \mathrm{O} / \mathrm{N}_{2}$ ratios in respect of the control, slurry-only, slurry plus DCD and slurry plus DMPP treatments were 1.26, 1.98, 0.04 and 0.08 , respectively. Both inhibitors were highly effective in lowering $\mathrm{N}_{2} \mathrm{O}$ emissions during the nitrification and denitrification phases.

Integration of the areas under the $\mathrm{CH}_{4}$ emission curves in Fig. 2 reveals that the amounts of $\mathrm{CH}_{4}-\mathrm{C}$ emitted from the slurry-only, slurry plus DCD and slurry plus DMPP treatments were $0.18,0.32$ and $0.24 \mathrm{~kg} \mathrm{C} \mathrm{ha}^{-1}$, respectively. Losses of $\mathrm{CH}_{4}$ from soil receiving the slurry plus DCD treatment were $33 \%$ greater $(P<0.05)$ than from soil receiving the slurry plus DMPP. Overall losses of $\mathrm{CH}_{4}$ may have been reduced by using sieved slurry, since this was shown to reduce the total VFA by about $66 \%$ (Table 2).

\section{Discussion}

The rates of emission and total fluxes obtained during the first (nitrification) phase of the present experiment, in response to addition of cattle slurry, were of the same order as those obtained in Spanish field experiments (Merino et al. 2001, 2002; Macadam et al. 2003). However, the effectiveness of the nitrification inhibitors was $100 \%$ in our laboratory experiment, but was only typically $40-60 \%$ effective in the field experiments. These inhibitors are less effective when applied with mineral fertilizers than with slurry to grassland (e.g. Merino et al. 2002) and were only $30-50 \%$ effective with mineral fertilizers applied to arable crops (Weiske et al. 2001). It cannot be concluded, however, that the efficiency of the inhibitors was poorer in the field experiments due to inherent differences between conditions in the field and laboratory. Pathak and Nedwell (2001) conducted highly controlled laboratory experiments in which $\mathrm{N}_{2} \mathrm{O}$ emissions (due to nitrification from applied urea) could be reduced by only $37 \%$ with DCD. The most likely reasons for the differential effectiveness of inhibitors are that: (1) in some soils the inhibitors are inactivated (degraded) more rapidly, (2) the soil and water regime pertaining during the experiment could cause physical separation of the inhibitor and $\mathrm{N}$ substrate (fertiliser, or manures) during the early part of the experiment, or (3) the inhibitor may not infiltrate all the sites where nitrification is most active. Field measurements (Weiske et al. 2001) have shown that only ca. $25 \%$ of the original concentrations of DCD and DMPP were still present in soil after a period equivalent to our incubation. However, consideration of the data presented in Fig. 3a (anaerobic phase), suggests that both inhibitors remained very effective, at least during phase 1. The inhibitors must have permeated the soil on application, as there was much less $\mathrm{NO}_{3}^{-}$in the soil receiving slurry plus inhibitors to be denitrified during phase 2. This was in contrast with the control and slurry-only treatments, which must have produced sufficient soil $\mathrm{NO}_{3}^{-}$during incubation to stimulate higher rates of $\mathrm{N}_{2} \mathrm{O}$ production (Fig. 3a), but with less efficient reduction through to $\mathrm{N}_{2}$ (Fig 3b).

In this second (denitrification) phase of the experiment, $\mathrm{N}_{2} \mathrm{O}$ emissions were large from both control and slurrytreated soil, relative to emissions obtained in some field experiments (e.g. Merino et al. 2001). However, the $\mathrm{N}_{2} \mathrm{O} /$ $\mathrm{N}_{2}$ ratios obtained in our experiments were similar to those obtained by others (e.g. Jarvis et al. 1994) using $\mathrm{C}_{2} \mathrm{H}_{2}$ inhibition (to prevent reduction of the $\mathrm{N}_{2} \mathrm{O}$ produced during denitrification of $\mathrm{NO}_{3}^{-}$from slurry) and to ratios obtained with denitrification of mineral fertilizers (Merino et al. 2001; Cardenas et al. 2003). The much smaller $\mathrm{N}_{2} \mathrm{O} / \mathrm{N}_{2}$ ratios obtained in phase 2 with the inhibitor treatments, compared with the control and slurry-only treatments are not readily explained. Possibly, the larger residual soil $\mathrm{NO}_{3}^{-}$ concentrations remaining in the control and slurry-only treatments (Table 1) inhibited nitrous oxide reductase, so that less $\mathrm{N}_{2}$ (Fig. 3b) was produced in these treatments (Weier et al. 1993).

The absence of $\mathrm{N}_{2}$ emission during phase 1 (0-31 days) and its presence during phase 2 (32-36 days) provides good support for the presumption that the main process giving rise to $\mathrm{N}_{2} \mathrm{O}$ during the first phase was nitrification and in the second phase denitrification. Further support is provided by the fact that the soil would have been too aerobic during phase 1 for significant denitrification, whereas during phase 2 , withholding $\mathrm{O}_{2}$ supply would have rapidly resulted in the onset of anoxic conditions, leading to a cessation of nitrification and the initiation of denitrification. Analysis of soil mineral $\mathrm{N}$ during the incubation could have provided further supporting (but not conclusive) evidence for the particular process involved, but it was recognised earlier that "analysis of soil $\mathrm{NO}_{3}^{-}$has contributed little to the understanding of the dynamics of the process" (Schmidt 1982). For example, the absence of $\mathrm{NO}_{3}^{-}$does not preclude rapid denitrification, which could be closely coupled to the supply of substrate, so that no $\mathrm{NO}_{3}^{-}$accumulates. In the present system, it is not currently possible to accommodate the necessary destructive sampling and still retain sufficient replication. Previous work (Bol et al. 2003) has been able to identify the source of $\mathrm{N}_{2} \mathrm{O}$ emissions by determining the ratios of the isotope and isotopomers produced and future developments in ion-selective electrodes could offer an alternative, non-invasive approach for continuous monitoring of soil mineral $\mathrm{N}$.

The diurnal patterns in emissions of the three gases $\left(\mathrm{N}_{2} \mathrm{O}\right.$, $\mathrm{N}_{2}$ and $\mathrm{CH}_{4}$ ) could have resulted from effects of changing temperature on either the rates of gas flow through the incubation system to the detectors, or on the rates of the 
biological processes in the soil, giving rise to the emissions. We ascertained that the first effect was not negligible, but could only possibly account for ca. $7.6 \%$ of the observed variation in $\mathrm{N}_{2} \mathrm{O}$ flux (Fig. 1). The detectors themselves were located outside the temperature-controlled cabinet and were operated at constant room temperature. Supporting evidence that the variations in $\mathrm{N}_{2} \mathrm{O}$ emission rates were biological in origin is provided by Figs. 1, 3a which show that, in general, the rates approximately doubled with the increase in temperature from $10^{\circ} \mathrm{C}$ to $20^{\circ} \mathrm{C}$ (i.e. $Q_{10} \approx 2$ ). Moreover, the peaks and troughs in emission rates lagged slightly behind those of soil temperature, indicating a response time for the biological system. While indications are that emission rates in the field would vary with temperature according to an approximate $Q_{10}=2$ relationship (Chadwick et al. 2000; Christensen 1983), this is the first report of such clear diurnal patterns measured over protracted periods. Failure to take account of these variations by, for example, sampling daily at midday, would give rise to large inaccuracies in calculation of total emissions.

The lag before the onset of $\mathrm{N}_{2} \mathrm{O}$ emission following application of slurry to the Portuguese soil ( 8 days) has been commonly observed in other studies and was found to range between ca. 4 days (Chadwick et al. 2000) and 30 days (Pathak and Nedwell 2001). The reason for a variable lag phase can only be speculated on, but could possibly be due to osmotic effects of the transfer of slurry to the main source of nitrifiers in the soil (Darrah et al. 1985). Alternatively, the lag could be due to the time taken for the slurry to permeate into the soil; a similar lag of 7 days was detected when cattle urine was applied in a field study (Yamulki et al. 2001), or was simply due to the time requirement for the nitrifier population to grow to a size responsible for the emissions observed.

The benefits of using a nitrification inhibitor could be considerable: $\mathrm{N}_{2} \mathrm{O}$ has a radiative effect which contributes approximately $5 \%$ to the current global warming potential (Bouwman et al. 1993). Taking the Portuguese situation as a model, the emission factor (EF) we found for slurry (without inhibitors) was $1.5 \%$ (from phase 1), compared with the widely quoted value of $1.25 \%$ (IPCC 1997), but still within the wide range of $\pm 1 \%$ (i.e. $0.25-2.25 \%$ ) which the official EF encompasses (Smith et al. 1997). With some 22 kt slurry$\mathrm{N}$ applied in Portugal per annum (H. Trindade, personal communication) and using the IPCC EF, this would give a potential emission of $275 \mathrm{t} \mathrm{N}_{2} \mathrm{O}-\mathrm{N}$. Our study has shown that under controlled conditions, DCD and DMPP can reduce these emissions by approximately 20 - and ten-fold, respectively, but the actual benefits under field conditions would depend on whether the inhibitor could remain active over protracted periods and in close proximity to the substrate. Also, it would appear that a small amount of $\mathrm{CH}_{4}$ emission could accompany the use of these inhibitors, which would need to be offset against any overall reduction in greenhouse gas emissions. An explanation for this may be the increased availability of $\mathrm{NH}_{4}^{+}-\mathrm{N}$ in the presence of inhibitors, which has been shown (Tlustos et al. 1999) to inhibit $\mathrm{CH}_{4}$ oxidation in both arable and grassland soils. Additionally, nitrification inhibitors may not only directly affect ammonia mono- oxygenase (the enzyme responsible for the first stage of nitrification performed by Nitrosomonas species), but also inhibit methane mono-oxygenase, found in $\mathrm{CH}_{4}$-oxidizing bacteria. Both enzymes have common inhibitors and substrates and methanotrophs are capable of oxidizing $\mathrm{NH}_{3}$ and Nitrosomonas can oxidize $\mathrm{CH}_{4}$, although each enzyme operates at a slower rate when using the alternative substrate (Prosser 1989).

However, the consequences of inhibiting nitrification need to be evaluated in the widest possible context, since preserving slurry- $\mathrm{N}$ as $\mathrm{NH}_{4}^{+}$could also enhance losses of $\mathrm{NH}_{3}$ by volatilization. The direct and indirect reduction of $\mathrm{N}_{2} \mathrm{O}$ is advantageous over other pollution mitigation as there will be little "downstream" enhancement of $\mathrm{NO}_{3}^{-}$ leaching. Nevertheless, $\mathrm{N}_{2} \mathrm{O}$ loss mitigation may also have consequences for $\mathrm{NO}_{3}^{-}$loss.

\section{Conclusions}

1. Use of an automated laboratory soil incubation system allowed close control and precision to enable the effects of soil amendments, including inhibitors, on gaseous emissions to be accurately quantified

2. Nitrification inhibitors applied with slurry under simulated Portuguese conditions were very efficient in reducing $\mathrm{N}_{2} \mathrm{O}$ emission, but were accompanied by small emissions in $\mathrm{CH}_{4}$. The inhibitors were also indirectly effective in reducing $\mathrm{N}_{2} \mathrm{O}$ emissions due to denitrification during a subsequent anaerobic phase

3. All gaseous emissions followed strong diurnal patterns that were positively correlated with soil temperature $\left(Q_{10} \approx 2\right)$.

4. The widespread use of DCD and DMPP inhibitors with slurry applied to Portuguese soils has the potential to reduce $\mathrm{N}_{2} \mathrm{O}$ emissions in that country by between tenand 20-fold, depending on the activity/persistence under field conditions.

Acknowledgements The authors would like to thank the following for their help in this work: A. Bristow, S. Brookman, E. Dixon and P. Hobbs. The DMPP and DCD inhibitors were provided by COMPO (Spain)/BASF (Germany) and Adubos de Portugal, respectively. We are grateful to the British Council (Treaty of Windsor Programme) and Conselho de Reitores das Universidades Portuguesas for providing additional funding. IGER is supported by the Biotechnology and Biological Sciences Research Council.

\section{References}

Bol R, Toyoda S, Yamulki S, Hawkins JMB, Cardenas LM, Yoshida $\mathrm{N}$ (2003) Dual isotope and isotopomer ratios of $\mathrm{N}_{2} \mathrm{O}$ emitted from a temperate grassland soil after fertiliser application. Rapid Commun Mass Spectrom 17:2550-2556

Bouwman AF, Fung I, Matthews E, John J (1993) Global analysis of the potential for $\mathrm{N}_{2} \mathrm{O}$ production in natural soils. Global Biogeochem Cycles 7:557-597

Cardenas LM, Hawkins JMB, Chadwick D, Scholefield D (2003) Biogenic gas emissions from soils measured using a new automated laboratory system. Soil Biol Biochem 35:867-870 
Chadwick D, Pain BF, Brookman SKE (2000) Nitrous oxide emissions following application of animal manures to grassland. J Environ Qual 29:277-287

Christensen S (1983) Nitrous oxide emission from soil under permanent grass: seasonal and diurnal fluctuations as influenced by manuring and fertilization. Soil Biol Biochem 15:531-536

Darrah PR, Nye PH, White RE (1985) Modelling growth responses of soil nitrifiers to additions of ammonium sulphate and ammonium chloride. Plant Soil 86:425-39

Dittert K, Bol R, King R, Chadwick D, Hatch D (2001) Use of a novel nitrification inhibitor to reduce nitrous oxide emission from $15 \mathrm{~N}$-labelled dairy slurry injected into soil. Rapid Commun Mass Spectrom 15:1291-1296

Erickson HE, Keller M (1997) Tropical land use change and soil emissions of nitrogen oxides. Soil Use Manage 13:278-287

Fettweis U, Mittelstaedt W, Schimansky C, Fuhr F (2001) Lysimeter studies on the translocation of the ${ }^{14} \mathrm{C}$-labelled nitrification inhibitor DMPP in a gleyic cambisol. Biol Fertil Soils 34:126-130

Hobbs PJ, Johnson R, Chadwick D (1999) A novel technique to determine organic processes in pig wastes. J Sci Food Agric 79:199-205

IPCC (Intergovernmental Panel on Climate Change) (1997) Greenhouse gas emissions from agricultural soils. In: Houghton JT, et al. (eds) Greenhouse gas inventory reference manual. Revised 1996 IPCC guidelines for national greenhouse gas inventories. IPCC, OECD, IES, UK Meteorological Office, Bracknell, Hertfordshire

Jarvis SC, Hatch DJ, Pain BF, Klarenbeek JV (1994) Denitrification and the evolution of nitrous oxide after the application of cattle slurry to a peat soil. Plant Soil 166:231-241

Kamphake LJ, Hannah SA, Cohen JM (1967) Automated analysis for nitrate by hydrazine reduction. Water Res 1:205-216

Macadam XMB, del Prado A, Merino P, Estavillo JM, Pinto M, Gonzales-Murua C (2003) Dicyandiamide and 3,4-dimethyl pyrazole phosphate decrease $\mathrm{N}_{2} \mathrm{O}$ emissions from grassland but dicyandiamide produces deleterious effects on clover. J Plant Physiol 160:1517-1523

Majumdar D, Pathak H, Kumar S, Jain MC (2002) Nitrous oxide emission from a sandy loam Incepticol under irrigated wheat in India as influenced by different nitrification inhibitors. Agric Ecosyst Environ 91:283-293

Merino P, Estavillo JM, Besga G, Pinto M, González-Mura C (2001) Nitrification and denitrification derived $\mathrm{N}_{2} \mathrm{O}$ production from grassland soil under application of DCD and Actilith F2. Nutr Cycl Agroecosyst 60:9-14

Merino P, Estavillo JM, Graciolli LA, Pinto M, Lacuesta M, MunozRueda A, Gonzalez-Murua C (2002) Mitigation of $\mathrm{N}_{2} \mathrm{O}$ emissions from grassland by nitrification inhibitor and Actilith F2 applied with fertilizer and cattle slurry. Soil Use Manage 18:135-141

Oenema O, Velthof GL, Yamulki S, Jarvis SC (1997) Nitrous oxide emissions from grassland. Soil Use Manage 13:288-295

Pathak H, Nedwell DB (2001) Nitrous oxide emission from soil with different fertilizers, water levels and nitrification inhibitors. Water Air Soil Pollut 129:217-228
Prosser IL (1989) Autotrophic nitrification in bacteria. Adv Microb Physiol 30:125-181

Sánchez L, Díez JA, Vallejo A, Cartagena MC (2001) Denitrification losses from irrigated crops in central Spain. Soil Biol Biochem 33:1201-1209

Schmidt EL (1982) Nitrification in soil. In: Nitrogen in agricultural soils. Agronomy Monograph No 22. Am Soc Agron, Madison, WI, pp 253-288

Scholefield D, Hawkins JMB, Jackson SM (1997) Development of a helium soil incubation technique for direct measurement of nitrous oxide and dinitrogen fluxes during denitrification. Soil Biol Biochem 29:1345-1352

Searle PL (1984) The Berhlot or indophenol reaction and its use in the analysis chemistry of nitrogen. Analyst 109:549-565

Smith KA, McTaggart IP, Tsuruta H (1997) Emissions of $\mathrm{N}_{2} \mathrm{O}$ and NO associated with nitrogen fertilization in intensive agriculture, and the potential for mitigation. Soil Use Manage 13:296-304

Teske W, Matzel W (1988) Die Beeinflussung der nitrifikationshemmenden Wirkung von Dicyandiamid durch Abbau und Verlagerung im Boden. Arch Acker Pflanzenbau Bodenkd 32:241-246

Tlustos P, Willison TW, Baker JC, Murphy DV, Pavlikova D, Goulding KWT, Powlson DS (1999) Short-term effects of nitrogen on methane oxidation in soils. Biol Fertil Soils 28:64 70

Trindade H, Coutinho J, van Beusichem ML, Scholefield D, Moreira N (1997) Nitrate leaching from sandy loam soils under a double-cropping forage system estimated from suction-probe measurements. Plant Soil 195:247-256

Vallejo A, Diez JA, Lopez-Valdivia LM, Gasco A, Jiménez C (2001) Nitrous oxide emission and denitrification nitrogen losses from soils treated with isobutylenediurea and urea plus dicyandiamide. Biol Fertil Soils 34:248-257

Weier KL, Doran JW, Power JF, Walters DT (1993) Denitrification and the dinitrogen/nitrous oxide ratio as affected by soil water, available carbon and nitrate. Soil Sci Soc Am J 57:66-72

Weiske A, Benckiser G, Herbert T, Ottow JCG (2001) Influence of the nitrification inhibitor 3,4-dimethylpyrazole phosphate (DMPP) in comparison to dicyandiamide (DCD) on nitrous oxide emissions, carbon dioxide fluxes and methane oxidation during 3 years of repeated application in field experiments. Biol Fertil Soils 34:109-117

Xu X, Boeckx P, van Cleepput O, Zhou L (2002) Urease and nitrification inhibitors to reduce emissions of $\mathrm{CH}_{4}$ and $\mathrm{N}_{2} \mathrm{O}$ in rice production. Nutr Cycl Agroecosyst 64:203-211

Yamulki S, Toyoda S, Yoshida N, Veldkamp E, Grant B, Bol R (2001) Diurnal fluxes and the isotopomer ratios of $\mathrm{N}_{2} \mathrm{O}$ in a temperate grassland following urine amendments. Rapid Commun Mass Spectrom 15:1263-1269

Zerulla W, Barth T, Dressel J, Erhardt K, von Locquenghein KH, Pasda G, Radle M, Wissemeier H (2001) 3,4-Dimethylpyrazole phosphate (DMPP) - a new nitrification inhibitor for agriculture and horticulture. Biol Fertil Soils 34:79-84 